\title{
Effect of rapeseed oil-derived plant sterol and stanol esters on atherosclerosis parameters in cholesterol-challenged heterozygous Watanabe Heritable Hyperlipidaemic rabbits
}

\author{
Malene Schrøder ${ }^{1}$, Christiane Fricke ${ }^{2}$, Kirsten Pilegaard ${ }^{1}$, Morten Poulsen ${ }^{1}$, Ingmar Wester ${ }^{3}$, \\ Dieter Lütjohann $^{2}$ and Alicja Mortensen ${ }^{1 *}$ \\ ${ }^{1}$ National Food Institute, Technical University of Denmark, Mørkhфj Bygade 19, DK 2860 Søborg, Denmark \\ ${ }^{2}$ Institute of Clinical Chemistry and Pharmacology, University of Bonn, Sigmund Freud Strasse 25, D 53105 Bonn, Germany \\ ${ }^{3}$ Raisio Group, PO Box 101, FI 21201 Raisio, Finland
}

(Received 26 November 2008 - Revised 19 April 2009 - Accepted 13 May 2009 - First published online 22 September 2009)

\begin{abstract}
Rapeseed oil (RSO) is a novel source of plant sterols, containing the unique brassicasterol in concentrations higher than allowed for plant sterol blends in food products in the European Union. Effects of RSO sterols and stanols on aortic atherosclerosis were studied in cholesterol-fed heterozygous Watanabe heritable hyperlipidaemic (Hh-WHHL) rabbits. Four groups ( $\mathrm{n} 18$ per group) received a cholesterol-added (2 g/kg) standard chow or this diet with added RSO stanol esters $(17 \mathrm{~g} / \mathrm{kg})$, RSO stanol esters $(34 \mathrm{~g} / \mathrm{kg})$ or RSO sterol esters $(34 \mathrm{~g} / \mathrm{kg})$ for 18 weeks. Feeding RSO stanol esters increased plasma campestanol $(P<0.001)$ and sitostanol $(P<0.001)$ and aortic campestanol $(P<0 \cdot 05)$ compared with controls. Feeding RSO sterol esters increased concentrations of plasma campesterol $(P<0.001)$, sitosterol $(P<0.001)$ and brassicasterol $(P<0.001)$ and aortic campesterol $(P<0 \cdot 01)$. Significantly lower plasma cholesterol $(P<0.001)$ was recorded in the treated groups after 3 weeks and throughout the study. LDL-cholesterol was reduced $50 \%$ in the high-dose RSO sterol ester $(P<0 \cdot 01)$ and high-dose RSO stanol ester $(P<0 \cdot 001)$ groups compared with controls. Atherosclerotic lesions were found in three rabbits in each of the RSO stanol ester groups and in one in the RSO sterol ester group. Aortic cholesterol was decreased in the treated groups $(P<0.001)$ in response to lowering of plasma cholesterol induced by RSO sterol and stanol esters. In conclusion, RSO stanol and sterol esters with a high concentration of brassicasterol were well tolerated. They were hypocholesterolaemic and inhibited experimental atherosclerosis in cholesterol-fed Hh-WHHL rabbits. A significant uptake of plant sterols into the blood and incorporation of campesterol and campestanol into aortic tissue was recorded.
\end{abstract}

Plant sterols: Plant stanols: Brassicasterol: Rapeseed oil: Atherosclerosis: Watanabe rabbits

Plant sterols and stanols have been on the European market for over a decade as a food ingredient added to certain food groups. They are being marketed as a natural means to lower blood cholesterol levels in humans ${ }^{(1)}$. Recently, the European Food Safety Authority has published opinions on the scientific substantiation of health claims related to both plant sterols and plant stanol esters and lower or reduced blood cholesterol and reduced risk of $\mathrm{CHD}^{(2,3)}$. The total and LDL-cholesterol-lowering effect of plant sterols has been shown in several human trials ${ }^{(4-10)}$. However, the effect of plant sterols on established atherosclerosis in humans is still unclear ${ }^{(9-13)}$. In animal models some authors have found that plant sterols reduce both hypercholesterolaemia and the development of aortic atherosclerosis ${ }^{(12,14-18)}$, while others report contradictionary results on the development of atherosclerosis ${ }^{(19)}$.

The major source of plant sterols used in food products is tall oil sterols and vegetable oil sterols, mainly from soyabean oil. In Northern and Central Europe one of the important sources of vegetable oil is rapeseed oil (RSO), since rape is widely grown in this region. RSO is a novel source of plant sterols and stanols, containing plant sterols in concentrations higher than in, for example, soyabean oil ${ }^{(20)}$. The composition of RSO plant sterol blends differs markedly from that found in other oils, since RSO contains the unique brassicasterol (Fig. 1) in concentrations of up to $15 \%{ }^{(21,22)}$. Plant sterol blends solely derived from RSO do not have the acceptable profile presently approved in the European Union ${ }^{(23)}$. Brassicasterol has not been accepted in concentrations above $5 \%$ of the plant sterol mixture, since it is still lacking the safety evaluation necessary for its use in food products. The effects of RSOderived plant sterol and stanol blends on plasma cholesterol and atherosclerosis is presumed to be comparable with those from oils of other origins.

The aim of the present study was to investigate the effect of dietary supplementation with RSO plant sterol and stanol esters on plasma cholesterol and development of experimental atherosclerosis in cholesterol-fed heterozygous Watanabe

Abbreviations: Hh-WHHL, heterozygous Watanabe heritable hyperlipidaemic; RSO, rapeseed oil.

* Corresponding author: Dr Alicja Mortensen, fax +45 7234 7699, email almo@food.dtu.dk 
<smiles>CCC(CCC(C)C1CCC2C3CC=C4CC(O)CCC4(C)C3CCC12C)C(C)C</smiles><smiles>CC(C)C(C)CCC(C)C1CCC2C3CC=C4CC(O)CCC4(C)C3CCC12C</smiles><smiles>CC(C)C(C)/C=C/C(C)C1CCC2C3CC=C4CC(O)CCC4(C)C3CCC12C</smiles>

Fig. 1. Molecular structures of sitosterol (a), campesterol (b) and brassicasterol (c)

heritable hyperlipidaemic (Hh-WHHL) rabbits. The HhWHHL rabbit has been proposed as a generally more suitable model for human atherosclerosis than the cholesterol-fed New Zealand White rabbit due to a greater morphological resemblance of the atherosclerotic lesions to human lesions ${ }^{(24,25)}$. Furthermore, this model simulates the human population better than the homozygous WHHL rabbit, since the number of individuals with heterozygous familial hypercholesterolaemia outnumber those with the homozygous form ${ }^{(26)}$.

The endpoints in the study included changes in blood lipids and evaluation of aortic atherosclerosis by biochemical analysis, macroscopic and histological examination. In addition, plasma content of individual plant sterols and stanols and their concentrations in aortic tissue in response to dietary exposure were measured. Furthermore, semi-quantitative histopathological evaluation was carried out on the small intestine, lung tissue and myocardium for macrophages, known to be increased in the myocardium of hypercholesterolaemic New Zealand White rabbits and in multiple organs of cholesterol-fed Hh-WHHL rabbits as a response to cholesterol over$\operatorname{load}^{(27,28)}$.

\section{Materials and methods}

Animals and housing

The animal study was performed under conditions approved by the Danish Agency for the Protection of Experimental Animals and the in-house Animal Welfare Committee.

Seventy-two Hh-WHHL rabbits of both sexes were obtained from our in-house breeding colony at the National Food Institute (derived from a parent generation from F. G. J. Janssen, University of Leiden, The Netherlands, with permission from Y. Watanabe). At 6 weeks of age the animals were allocated randomly to four treatment groups. Littermates were assigned to different treatment groups. The animals were kept individually in stainless-steel cages under controlled environmental conditions (temperature $18 \pm 2^{\circ} \mathrm{C} ; 12 \mathrm{~h}$ light$12 \mathrm{~h}$ dark cycle; relative humidity $55 \pm 5 \%$; air change ten times per $\mathrm{h}$ ) and observed twice daily for any abnormal behaviour or clinical condition. Body weight was recorded weekly and feed intake daily. The animals had free access to tap water.

\section{Experimental design}

The test compounds were mixed into a standard rabbit chow (Altromin no. 2123; Altromin International, Lage, Germany) containing (per $\mathrm{kg}$ ): crude protein, $120 \mathrm{~g}$; crude fat, $30 \mathrm{~g}$; crude fibre, $200 \mathrm{~g}$; ash, $90 \mathrm{~g}$; moisture, $120 \mathrm{~g}$; N-free extract, $440 \mathrm{~g}$; metabolisable energy, 9.7 MJ. The animals were fed a restricted diet of $100 \mathrm{~g} / \mathrm{d}$ for a total of 18 weeks ( \pm 2 weeks).

The control group ( $n$ 18) received daily the standard diet with added cholesterol (2 g/kg) (C 8503; Sigma Aldrich Denmark A/S, Vallensbæk Strand, Denmark). The treated groups ( $n 18$ per group) received daily the standard diet with added RSO stanol esters $(17 \mathrm{~g} / \mathrm{kg}$; about $10 \mathrm{~g}$ plant stanols $/ \mathrm{kg})$ + cholesterol $(2 \mathrm{~g} / \mathrm{kg})$, or RSO stanol esters $(34 \mathrm{~g} / \mathrm{kg}$; about $20 \mathrm{~g}$ plant stanols $/ \mathrm{kg})+$ cholesterol $(2 \mathrm{~g} / \mathrm{kg})$, or RSO sterol esters $(34 \mathrm{~g} / \mathrm{kg}$; about $20 \mathrm{~g}$ plant sterols $/ \mathrm{kg})+$ cholesterol $(2 \mathrm{~g} / \mathrm{kg})$, respectively. The experimental diets were analysed for contents of cholesterol and the following plant sterols and stanols: brassicasterol, campesterol, sitosterol, campestanol and sitostanol (Table 1); for methodology, see Fricke et al. ${ }^{(29)}$. The concentration of brassicasterol in the feed was $1.8 \mathrm{~g} / \mathrm{kg}$, about $10 \%$ of the total plant sterol content (about $20 \mathrm{~g}$ plant sterols $/ \mathrm{kg}$ ). RSO sterol and stanol ester blends were produced by Raisio Group (Raisio, Finland).

After the 18-week feeding period the animals were euthanised by intravenous injection of pentobarbital $(100 \mathrm{mg} / \mathrm{kg})$ into the marginal ear vein followed by exsanguination via flushing of the blood system with $300 \mathrm{ml}$ chilled $0.9 \% \mathrm{NaCl}$ solution through a needle inserted into the right ventricle of the heart.

\section{Sampling and analysis of blood}

Blood was collected at the initiation of the study before the first experimental feeding and every 3rd week in heparincoated tubes from the marginal ear vein of unanaesthetised animals fasted overnight. The blood was routinely placed on a rotation bed until centrifugation $(2500 \mathrm{~g} ; 15 \mathrm{~min})$. Plasma was collected and kept frozen at $-20^{\circ} \mathrm{C}$ until further analysed. For lipoprotein fractioning, additional blood samples were 
Table 1. Concentrations of cholesterol and plant sterols and stanols in experimental diets $(\mathrm{g} / \mathrm{kg} \text { feed })^{*}$ (Mean values of triplicate analyses)

\begin{tabular}{llccc}
\hline Group... & Control & RSO stanol ester $(17 \mathrm{~g} / \mathrm{kg})$ & RSO stanol ester $(34 \mathrm{~g} / \mathrm{kg})$ & RSO sterol ester $(34 \mathrm{~g} / \mathrm{kg})$ \\
\hline Cholesterol & 1.97 & 2.11 & 2.04 & 1.91 \\
Plant sterols & & & & 7.53 \\
$\quad$ Campesterol & 0.09 & 0.11 & 0.21 & 9.69 \\
$\quad$ Sitosterol & 0.33 & 0.36 & 0.41 & 1.97 \\
$\quad$ Brassicasterol & 0.003 & 0.010 & 0.022 & 19.2 \\
$\quad$ Total plant sterols & 0.42 & 0.48 & 0.64 & 0.17 \\
Plant stanols & & 4.76 & 9.46 & 0.16 \\
$\quad$ Campestanol & 0.04 & 5.68 & 11.4 & 0.33 \\
$\quad$ Sitostanol & 0.17 & 10.4 & 20.8 & 19.5 \\
$\quad$ Total plant stanols & 0.21 & 10.9 & 21.4 & \\
Total phytosterols & 0.6 & & & \\
\hline
\end{tabular}

RSO, rapeseed oil.

* Part of these data has been previously published by Fricke et al. ${ }^{(29)}$

taken on the day of killing. The lipoproteins were separated by density gradient ultracentrifugation $(100000 \mathrm{~g})$ for $18 \mathrm{~h}$ at room temperature as described by Terpstra et al. ${ }^{(30)}$. The lipoproteins were separated into four fractions containing HDL, intermediate-density lipoprotein, LDL and VLDL. The concentrations of cholesterol and TAG in plasma and in the four lipoprotein fractions were measured enzymically on an automatic analyser (Roche/Hitachi 912 system; Roche Diagnostics, Indianapolis, IN, USA) by the use of appropriate kits (CHOD-PAP 1489232 216, GPO-PAP 1488872 2169; Roche Diagnostics).

\section{Evaluation of aortic atherosclerosis}

The aorta was excised from the body in its total length from the heart to the bifurcation of the iliac arteries for macroscopic and microscopic quantitative and qualitative evaluation of atherosclerosis.

For microscopic examination, three ring-sections were excised from well-defined places on the unopened aorta: (1) just above the aortic valves, (2) at the level of the first intercostal arteries and (3) cranial to the coeliac artery. The three ring-sections were fixed for a minimum of $24 \mathrm{~h}$ in $4 \%$ neutral buffered formaldehyde, before embedding in paraffin. Sections, $4-6 \mu \mathrm{m}$ thick, were stained with van Gieson's stain. In each of the three ring-sections of aorta the lesions were evaluated qualitatively by microscopy as either: (1) fatty streaks as subintimal accumulation of foam cells, (2) fibrous plaques as localised intimal thickening with occasional foam cells and without cholesterol crystals, or (3) advanced lesions as intimal thickening and loosening of the intimal membrane, many foam cells and eventual cholesterol crystals located in deep-seated pools ${ }^{(31)}$. To evaluate quantitatively the severity of atherosclerosis, stereology was performed by methodologies previously described as point counting on each of the three ring-sections of aorta ${ }^{(32)}$.

For macroscopic examination the three remaining parts of the aorta: (a) cranial, (b) thoracic and (c) abdominal were cut open and scanned separately on a standard document scanner (HP ScanJet 7400c; Hewlett Packard, Palo Alto, CA, USA). Quantitative evaluation of the extent of atherosclerosis measured as the percentages of aorta covered by plaque was performed using quantification software (Quantity One, version 4.2; Bio-Rad Laboratories, Hercules, CA, USA) to measure the area of the plaque and the area of the aorta. The intima-inner media was then stripped from the rest of the aortic wall of the cranial aorta, weighed, frozen and stored at $-20^{\circ} \mathrm{C}$ until further analysed. Cholesterol and lathosterol content in the cranial aorta was determined biochemically by $\mathrm{GC}$-flame ionisation detection as described previously ${ }^{(33)}$ and concentrations given in ng/mg dry weight.

\section{Analysis for plant sterols in plasma and cranial aorta}

Plant sterol levels were measured in plasma on day 1 and at termination, by $\mathrm{GC}$-flame ionisation detection methods described by Fricke et al. ${ }^{(29)}$. Intima-media of the cranial aorta was analysed for plant sterols by GC-MS-selected ion monitoring according to Lütjohann et al. ${ }^{(33)}$.

\section{Histological evaluation of other tissues}

Tissue samples were collected at the time of killing from the duodenum, the right lung and the myocardium. Tissues were fixed and embedded in paraffin as described for aortic tissues. Sections, 4-6 $\mu \mathrm{m}$ thick, were stained with standard haematoxylin and eosin. The sections were subjected to a semiquantitative evaluation of infiltration with macrophages and scored as no, slight or pronounced infiltration.

\section{Statistics}

Data were tested for normal distribution and homogeneity of variance by standard residual plots. Normally distributed data were analysed by the generalised linear model (GLM) procedure. Analysis of repeated measures was applied to data on blood (cholesterol and TAG), using the mixed procedure and analysis of summary measures was applied to data on plant sterols in plasma. Data not normally distributed was analysed by the Kruskall-Wallis test and if significant followed by Wilcoxon's test for pair-wise comparisons. Fisher's exact test was used to analyse data obtained from histological examinations. Differences were always considered statistically significant when $P<0 \cdot 05$. All statistic analyses were carried out using SAS Enterprise Guide 3.0 (SAS Institute Inc., Cary, NC, USA). 
Statistical analyses revealed an outlier in the low-dose RSO stanol ester group. Plasma concentrations of cholesterol, plant sterols and stanols were approximately two times higher in this animal than the mean of the group and the concentrations in intima of the cranial aorta were approximately ten times higher. Furthermore, cholesterol in both plasma and intima was higher in this animal than in the control group, so the animal was obviously responding abnormally to the treatment and was therefore excluded from the dataset.

\section{Results}

\section{Clinical parameters}

Feeding a standard rabbit chow containing cholesterol with or without RSO sterol or stanol esters in different concentrations had no effect on the clinical appearance of the rabbits. No significant differences were observed between the groups on body weight, weight gain, daily feed consumption or relative feed intake (Table 2). In the $34 \mathrm{~g} / \mathrm{kg}$ RSO stanol ester group, one rabbit was euthanised after 13 weeks of experimental feeding due to disturbed clinical appearance; autopsy showed no changes related to treatment.

\section{Plant sterols}

In plasma. Campesterol, sitosterol, brassicasterol, campestanol and sitostanol were found in measurable concentrations in plasma of all four treatment groups (Table 3). RSO sterol ester feeding caused significantly higher concentrations of campesterol $(P<0 \cdot 001)$, sitosterol $(P<0 \cdot 001)$ and brassicasterol $(P<0.001)$ in plasma compared with the control group. The brassicasterol concentration was $0.6 \%$ of total plant sterols in plasma in the RSO sterol ester group compared with $0.7 \%$ in controls. The percentage of total plant sterols to cholesterol in the RSO sterol ester group was increased to $12 \%(P<0.001)$ compared with $0.9 \%$ in the control group.

In both the low- and high-dose RSO stanol ester groups when compared with controls, increased campestanol $(P<0.001)$ and sitostanol $(P<0.001)$ concentrations were observed, but there were no significant differences in the plant stanol concentrations between the two RSO stanol ester groups. The percentage of plant stanols to cholesterol was increased in both the low-dose and the high-dose RSO stanol ester groups $(P<0 \cdot 001)$ when compared with the control group.

In both RSO stanol ester groups, significantly lower concentrations of campesterol $(P<0.01)$, sitosterol $(P<0.001)$ and brassicasterol (low dose, $P<0.05$; high dose, $P<0.01$ ) were observed compared with the control group.

In cranial aorta. Campesterol, sitosterol, brassicasterol, campestanol and sitostanol were found in measurable concentrations in aortic tissue of all four treatment groups (Table 3). In the RSO sterol ester group an increased concentration of campesterol $(P<0 \cdot 01)$ was recorded compared with the control group. Sitosterol was significantly lower $(P<0 \cdot 001)$ and the brassicasterol concentration in this group was comparable with the control group. The percentage of total plant sterols to cholesterol in the RSO sterol ester group was increased significantly $(P<0.001)$ when compared with the control group.

In the RSO stanol ester groups concentrations of campestanol in aortic tissue were increased in the low-dose group $(P<0.01)$ and in the high-dose group $(P<0.05)$ when compared with the controls. Sitostanol concentrations in the RSO stanol ester groups were comparable with the concentrations in the control group. The total plant stanol concentration was comparable between the two RSO stanol ester groups. The percentage of plant stanols to cholesterol in cranial aorta was increased both in the low-dose RSO stanol ester group $(P<0.001)$ and in the high-dose RSO stanol ester group $(P<0 \cdot 001)$ compared with the control group. In both of the RSO stanol ester groups significantly decreased concentrations $(P<0.001)$ of all three sterols (campesterol, sitosterol and brassicasterol) were found.

\section{Blood lipids}

Plasma cholesterol was significantly lower in all treated groups after the 3rd week of treatment and throughout the study compared with the control group (Fig. 2). There were no significant differences in plasma cholesterol concentrations between the RSO sterol and the two RSO stanol ester groups.

Lathosterol was significantly lower in plasma of all three treated groups compared with the control group (Table 3),

Table 2. Body weight (BW), weekly weight gain, relative feed intake and dose of the test compounds during and after rapeseed oil (RSO) stanol or sterol ester feeding for 18 weeks

(Mean values and standard deviations for seventeen or eighteen rabbits per group)

\begin{tabular}{|c|c|c|c|c|c|c|c|c|}
\hline \multirow[t]{2}{*}{ Group... } & \multicolumn{2}{|c|}{ Control } & \multicolumn{2}{|c|}{$\begin{array}{c}\text { RSO stanol } \\
\text { ester }(17 \mathrm{~g} / \mathrm{kg})\end{array}$} & \multicolumn{2}{|c|}{$\begin{array}{c}\text { RSO stanol } \\
\text { ester }(34 \mathrm{~g} / \mathrm{kg})\end{array}$} & \multicolumn{2}{|c|}{$\begin{array}{c}\text { RSO sterol } \\
\text { ester }(34 \mathrm{~g} / \mathrm{kg})\end{array}$} \\
\hline & Mean & SD & Mean & SD & Mean & SD & Mean & SD \\
\hline Animals per group $(n)$ & \multicolumn{2}{|c|}{18} & \multicolumn{2}{|c|}{17} & \multicolumn{2}{|c|}{17} & \multicolumn{2}{|c|}{18} \\
\hline \multicolumn{9}{|l|}{$\mathrm{BW}(\mathrm{kg})$} \\
\hline Initial & 0.97 & 0.14 & 0.98 & 0.16 & 1.00 & $0 \cdot 16$ & 1.04 & $0 \cdot 19$ \\
\hline At termination & $2 \cdot 86$ & 0.17 & $2 \cdot 87$ & 0.13 & $2 \cdot 84$ & 0.15 & $2 \cdot 85$ & 0.23 \\
\hline Weight gain per week (g) & 102 & 86 & 99 & 80 & 95 & 75 & 95 & 84 \\
\hline Relative feed intake (g/kg BW per d) & 51 & 16 & 50 & 16 & 51 & 15 & 50 & 14 \\
\hline \multicolumn{9}{|l|}{ Dose of test compound ( $\mathrm{g} / \mathrm{kg}$ BW per $\mathrm{d}$ ) } \\
\hline Total stanol esters & - & - & 0.9 & 0.3 & $1 \cdot 7$ & 0.5 & - & - \\
\hline Total sterol esters & - & - & - & - & - & - & $1 \cdot 7$ & 0.5 \\
\hline Cholesterol & $0 \cdot 1$ & 0.03 & $0 \cdot 1$ & 0.03 & $0 \cdot 1$ & 0.03 & $0 \cdot 1$ & 0.03 \\
\hline
\end{tabular}


Table 3. Concentrations of cholesterol, plant sterols and stanols in plasma and in cranial aorta measured by GC-flame ionisation detection after rapeseed oil (RSO) stanol or sterol ester feeding for 18 weeks $\dagger$

(Mean values and standard deviations for seventeen or eighteen rabbits per group)

\begin{tabular}{|c|c|c|c|c|c|c|c|c|}
\hline \multirow[t]{2}{*}{ Group... } & \multicolumn{2}{|c|}{ Control } & \multicolumn{2}{|c|}{$\begin{array}{l}\text { RSO stanol ester } \\
(17 \mathrm{~g} / \mathrm{kg})\end{array}$} & \multicolumn{2}{|c|}{$\begin{array}{l}\text { RSO stanol ester } \\
(34 \mathrm{~g} / \mathrm{kg})\end{array}$} & \multicolumn{2}{|c|}{$\begin{array}{l}\text { RSO sterol ester } \\
\quad(34 \mathrm{~g} / \mathrm{kg})\end{array}$} \\
\hline & Mean & SD & Mean & SD & Mean & SD & Mean & SD \\
\hline \multicolumn{9}{|l|}{ Plasma } \\
\hline Cholesterol (mmol/l) & 13.9 & 9.8 & $6 \cdot 8^{\star \star \star}$ & 4.6 & $5 \cdot 2^{\star \star \star}$ & 3.4 & $5 \cdot 3^{\star \star}$ & $3 \cdot 3$ \\
\hline Lathosterol $(\mu \mathrm{mol} / \mathrm{l})$ & $8 \cdot 7$ & 7.6 & $3 \cdot 7^{\star}$ & $2 \cdot 8$ & $2 \cdot 4^{\star \star \star}$ & $2 \cdot 0$ & $3 \cdot 3^{\star \star}$ & $3 \cdot 0$ \\
\hline Lathosterol:cholesterol (\%) & 0.06 & 0.02 & 0.06 & 0.02 & 0.05 & 0.01 & 0.06 & 0.02 \\
\hline \multicolumn{9}{|l|}{ Plant sterols } \\
\hline Campesterol $(\mu \mathrm{mol} / \mathrm{l})$ & $95 \cdot 3$ & 89.0 & $35 \cdot 0^{* *}$ & $27 \cdot 0$ & $24 \cdot 8^{\star \star}$ & $16 \cdot 7$ & $561^{* * *}$ & 348 \\
\hline Sitosterol $(\mu \mathrm{mol} / \mathrm{l})$ & $24 \cdot 0$ & $17 \cdot 8$ & $8 \cdot 7^{\star \star \star}$ & 4.5 & $6 \cdot 1^{\star \star \star}$ & $3 \cdot 2$ & $47 \cdot 2^{\star \star \star}$ & 28.4 \\
\hline Brassicasterol $(\mu \mathrm{mol} / \mathrm{l})$ & 0.84 & 0.63 & $0.45^{\star}$ & 0.20 & $0.36^{\star \star}$ & 0.09 & $3 \cdot 7^{\star \star \star}$ & $2 \cdot 6$ \\
\hline Total plant sterols $(\mu \mathrm{mol} / \mathrm{l})$ & $120 \cdot 1$ & & $44 \cdot 2^{\star \star \star}$ & & $31 \cdot 3^{\star \star \star}$ & & $612^{\star \star \star}$ & \\
\hline Plant sterols:cholesterol (\%) & 0.9 & & $0.7^{\star}$ & & $0.6^{*}$ & & $12^{\star \star \star}$ & \\
\hline \multicolumn{9}{|l|}{ Plant stanols } \\
\hline Campestanol $(\mu \mathrm{mol} / \mathrm{l})$ & 2.9 & 2.5 & $22 \cdot 1^{\star \star \star}$ & 13.1 & $20 \cdot 3^{\star \star \star}$ & $9 \cdot 7$ & $5 \cdot 3^{\star \star \star}$ & $2 \cdot 0$ \\
\hline Sitostanol $(\mu \mathrm{mol} / \mathrm{l})$ & 0.81 & 0.69 & $4 \cdot 0^{\star \star \star}$ & $2 \cdot 4$ & $3 \cdot 7^{\star \star \star}$ & $2 \cdot 3$ & 0.87 & 0.58 \\
\hline Total plant stanols $(\mu \mathrm{mol} / \mathrm{l})$ & $3 \cdot 7$ & & $26 \cdot 1^{\star \star \star}$ & & $24 \cdot 0^{\star \star \star}$ & & $6 \cdot 2^{\star \star \star}$ & \\
\hline Plant stanols:cholesterol (\%) & 0.03 & & $0.4^{\star \star *}$ & & $0.5^{\star \star \star}$ & & $0 \cdot 1^{\star \star \star}$ & \\
\hline Phytosterols:cholesterol (\%) $\ddagger$ & 0.9 & & $1.0^{*}$ & & $1.0^{* *}$ & & $12^{\star \star \star}$ & \\
\hline \multicolumn{9}{|l|}{ Cranial aorta } \\
\hline Cholesterol ( $\mu \mathrm{g} / \mathrm{mg}$ dry wt) & 74.5 & 59.7 & $9 \cdot 9^{\star \star \star}$ & $6 \cdot 8$ & $7 \cdot 4^{\star \star \star}$ & $3 \cdot 7$ & $8 \cdot 3^{\star \star \star}$ & $7 \cdot 9$ \\
\hline Lathosterol (ng/mg dry wt) & $23 \cdot 0$ & $16 \cdot 8$ & $9 \cdot 1^{\star \star \star}$ & 3.7 & $8 \cdot 9^{\star \star \star}$ & 3.4 & $8 \cdot 8^{\star \star \star}$ & $2 \cdot 8$ \\
\hline Lathosterol:cholesterol (\%) & 0.03 & & $0 \cdot 1^{* *}$ & & $0 \cdot 1^{\star \star \star}$ & & $0.1^{\star \star \star}$ & \\
\hline \multicolumn{9}{|l|}{ Plant sterols } \\
\hline Campesterol (ng/mg dry wt) & 449 & 454 & $40 \cdot 6^{\star \star \star}$ & 38.9 & $29 \cdot 7^{\star \star \star}$ & $20 \cdot 5$ & $767^{\star *}$ & 794 \\
\hline Sitosterol (ng/mg dry wt) & 120 & 105 & $14 \cdot 5^{\star \star \star}$ & $10 \cdot 4$ & $10 \cdot 9^{\star \star \star}$ & $5 \cdot 3$ & $47 \cdot 2^{\star \star}$ & 41.6 \\
\hline Brassicasterol (ng/mg dry wt) & $6 \cdot 4$ & $5 \cdot 7$ & $1.5^{\star \star \star}$ & 0.5 & $1 \cdot 5^{\star \star \star}$ & 0.6 & 5.4 & $7 \cdot 7$ \\
\hline Total plant sterols (ng/mg dry wt) & 576 & & $56 \cdot 6^{\star \star \star}$ & & $41 \cdot 5^{\star \star \star}$ & & $825^{\star}$ & \\
\hline Plant sterols:cholesterol (\%) & 0.8 & & $0.6^{\star \star}$ & & 0.6 & & $10^{\star \star \star}$ & \\
\hline \multicolumn{9}{|l|}{ Plant stanols } \\
\hline Campestanol (ng/mg dry wt) & $20 \cdot 6$ & 23.3 & $26 \cdot 2^{*}$ & $18 \cdot 7$ & $23 \cdot 9^{\star}$ & $10 \cdot 2$ & 11.5 & $9 \cdot 6$ \\
\hline Sitostanol (ng/mg dry wt) & $4 \cdot 8$ & 4.5 & $4 \cdot 1$ & $2 \cdot 6$ & 3.4 & 1.9 & $1 \cdot 2^{\star \star \star}$ & 1.0 \\
\hline Total plant stanols ( $\mathrm{ng} / \mathrm{mg}$ dry $\mathrm{wt}$ ) & $25 \cdot 4$ & & $30 \cdot 3$ & & $27 \cdot 3$ & & $12 \cdot 7$ & \\
\hline Plant stanols:cholesterol (\%) & 0.03 & & $0.3^{\star \star \star}$ & & $0.4^{\star \star \star}$ & & $0 \cdot 2^{\star \star *}$ & \\
\hline Phytosterols:cholesterol (\%)‡ & 0.8 & & 0.9 & & 1.0 & & $10^{\star * \star}$ & \\
\hline
\end{tabular}

Mean value was significantly different from that of the control group: ${ }^{*} P<0.05,{ }^{* *} P<0.01,{ }^{* \star *} P<0.001$.

$\dagger$ Part of these data has been previously published by Fricke et al. ${ }^{(29)}$.

$\ddagger$ Phytosterols $=$ plant sterols + plant stanols.

whereas the percentage of lathosterol to cholesterol was comparable between the treated groups and the control group.

LDL-cholesterol was significantly decreased in both the high-dose RSO stanol ester group $(P<0.001)$ and the RSO sterol ester group $(P<0 \cdot 01)$ as compared with controls (Fig. 3). In both high-dose groups the reduction was over $50 \%$ of the control value.
Plasma TAG decreased significantly in the control group and the two RSO stanol ester groups from the initiation of the study to week 6 , whereas this decrease was not significant in the RSO sterol ester group (Fig. 4). In both the RSO stanol ester groups plasma TAG concentrations were comparable with control values for the duration of the study. In the RSO sterol ester group a significantly higher plasma TAG

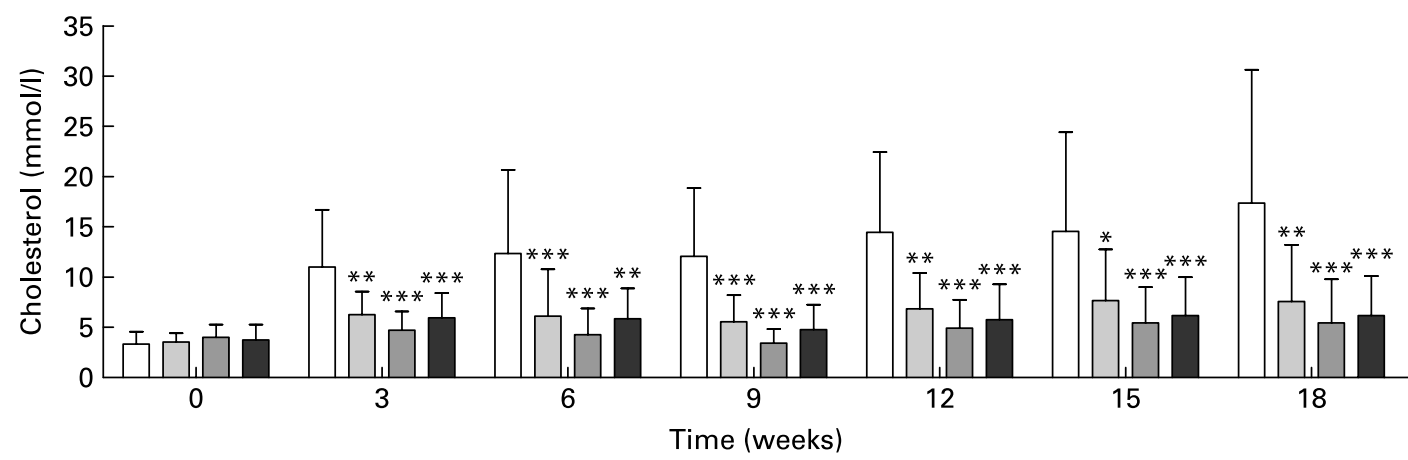

Fig. 2. Cholesterol concentrations in plasma measured enzymically during and after rapeseed oil (RSO) stanol or sterol ester feeding for 18 weeks. ( $\square$ ), Control group; ( $\square$ ), RSO stanol ester (17 g/kg) group; $(\square)$, RSO stanol ester (34 g/kg) group; $(\square)$, RSO sterol ester (34 g/kg) group. Values are means, with standard deviations represented by vertical bars. Mean value was significantly different from that of the control group: ${ }^{\star} P<0.05,{ }^{\star \star} P<0.01,{ }^{\star \star \star} P<0.001$. 


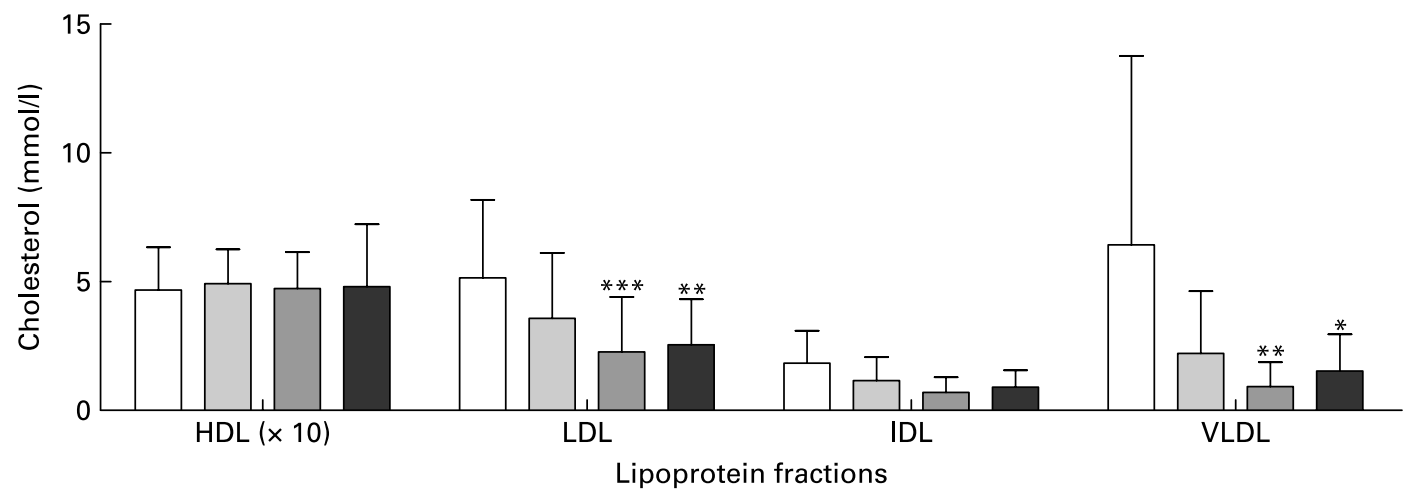

Fig. 3. Cholesterol in lipoprotein fractions measured enzymically after rapeseed oil (RSO) stanol or sterol ester feeding for 18 weeks. ( $\square$ ), Control group;

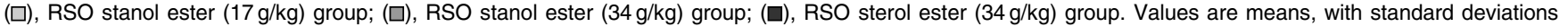
represented by vertical bars. Note that HDL-cholesterol values are multiplied by 10. IDL, intermediate-density lipoprotein. Mean value was significantly different from that of the control group: ${ }^{*} P<0.05,{ }^{\star \star} P<0.01,{ }^{\star \star \star} P<0.001$.

concentration was recorded in the 3rd week when compared with the control group and both RSO stanol ester groups and from week 9 throughout the rest of the study when compared with controls. In this group TAG was also significantly higher than in the low-dose RSO stanol ester group in weeks 9,12 and 18 . There were no statistically significant differences in the distribution of TAG in lipoproteins between the RSO stanol and sterol ester groups when compared with the control group (Fig. 5).

\section{Aortic atherosclerosis}

Biochemical evaluation of cranial aorta. The cholesterol content in intima of the cranial aorta was significantly reduced $(P<0.001)$ in all RSO stanol and sterol ester groups compared with controls (Table 3 ).

Total lathosterol was significantly reduced in all three treated groups $(P<0.001)$ compared with the control group (Table 3). The percentage of lathosterol to cholesterol was significantly increased in the low-dose RSO stanol ester group $(P<0.01)$ and in the high-dose RSO stanol and sterol ester groups $(P<0 \cdot 001)$ compared with controls.

Morphological evaluation. Macroscopic examination revealed thirteen rabbits in the control group with aortic atherosclerosis, whereas there were only three rabbits in each of the RSO stanol ester groups and one in the RSO sterol ester group (Table 4).

In the control group, $36 \%$ of cranial aorta, $26 \%$ of thoracic aorta and $15 \%$ of abdominal aorta was covered with plaque (Fig. 6). In the treated groups the total area of the aorta covered with plaque varied between 0 and $2 \%$, the area being the largest in the low-dose RSO stanol ester group.

Microscopic examination revealed that significantly more animals from the control group had atherosclerotic lesions in the three ring-sections from the aorta compared with the RSO stanol and sterol ester groups. In the controls all three lesion types were present and more severe lesions were seen in the more caudal parts of the aorta (Table 5). In the lowdose RSO stanol ester group and the RSO sterol ester group three and two rabbits, respectively, had lesions evaluated as fatty streaks or fibrous plaques. In the high-dose RSO stanol ester group no atherosclerotic plaques were observed.

\section{Correlations between percentage of phytosterols to cholesterol in plasma and intima}

There was a strong positive correlation between plasma and intima of the percentage of phytosterols (plant sterol + plant

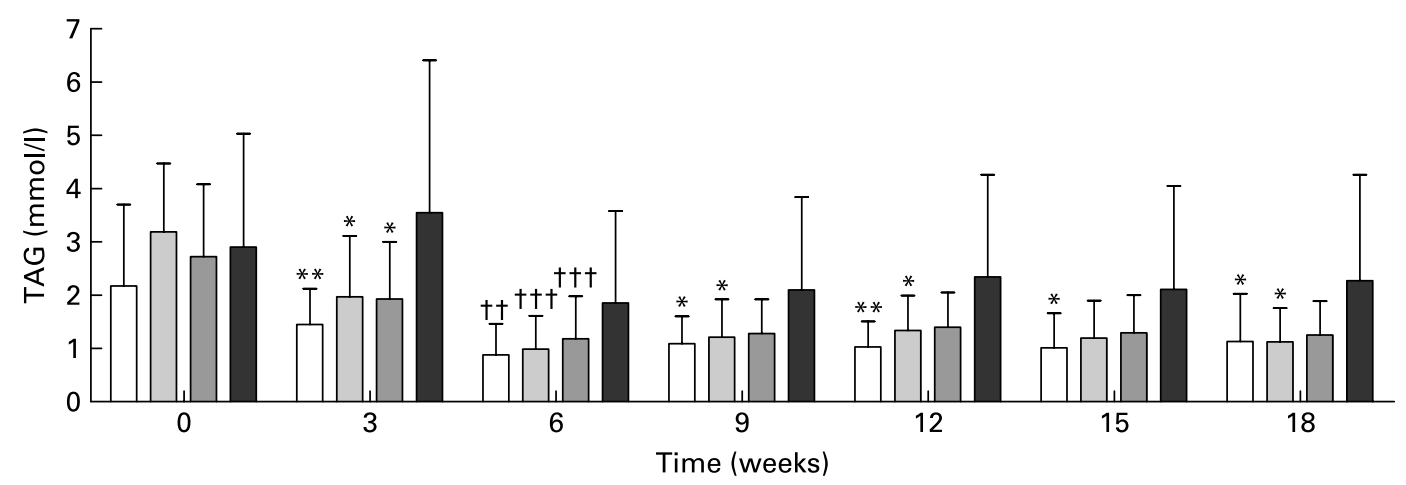

Fig. 4. TAG concentrations in plasma measured enzymically during and after rapeseed oil (RSO) stanol or sterol ester feeding for 18 weeks. ( $\square$ ), Control group;

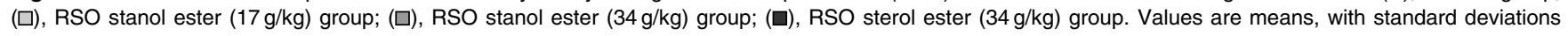
represented by vertical bars. TAG concentrations were higher in the RSO sterol ester group than in the control group and both RSO stanol ester groups throughout the study. Mean value was significantly different from that of the RSO sterol ester group: ${ }^{*} P<0.05,{ }^{\star *} P<0.01$. After 6 weeks the control group and both RSO stanol ester groups, but not the RSO sterol ester group, had significantly lower TAG as compared with baseline values. Mean value was significantly different from that at baseline in the same group: $\dagger \dagger P<0.01,+\dagger \dagger P<0.001$. 


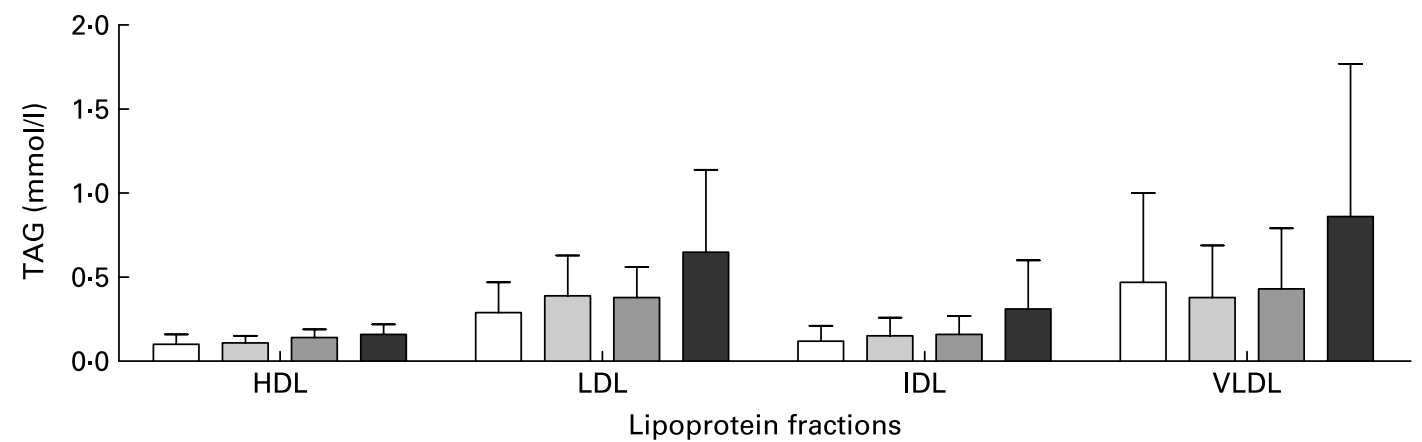

Fig. 5. TAG in lipoprotein fractions measured enzymically after rapeseed oil (RSO) stanol or sterol ester feeding for 18 weeks. ( $\square$ ), Control group; ( $\square$ ), RSO stanol

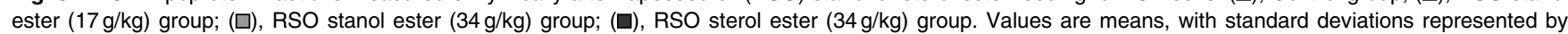
vertical bars. IDL, intermediate-density lipoprotein. There were no statistical differences between the groups in each fraction.

stanols) to cholesterol (control group, $r 0 \cdot 93, P<0 \cdot 001$; low-RSO stanol ester group, $r 0 \cdot 60, P<0 \cdot 05$; high-RSO stanol ester group, $r 0.51, P<0 \cdot 05$; RSO sterol ester group, $r 0.50, P<0 \cdot 05$ ).

\section{Semi-quantitative evaluation of tissue for macrophages}

Animals of all groups had infiltrations with macrophages in submucosa of the duodenum. In the groups fed high doses of RSO sterol or stanol esters the accumulation of macrophages was pronounced and significantly increased when compared with controls $(P<0.05)$ (Fig. 7). In lung tissue slight infiltrations with macrophages mainly around the larger arteries were found in animals of all four treatment groups, with no significant differences between the groups (Fig. 7). Infiltrations with macrophages in the myocardium were not observed in any of the groups.

Table 4. Macroscopic and microscopic quantitative evaluation of plaques (extent and severity of atherosclerosis) after rapeseed oil (RSO) stanol or sterol ester feeding for 18 weeks

(Mean values and standard deviations)

\begin{tabular}{|c|c|c|c|c|c|c|c|c|}
\hline \multirow[t]{2}{*}{ Group. . } & \multicolumn{2}{|c|}{ Control } & \multicolumn{2}{|c|}{$\begin{array}{l}\text { RSO stanol } \\
\text { ester }(17 \mathrm{~g} / \mathrm{kg})\end{array}$} & \multicolumn{2}{|c|}{$\begin{array}{l}\text { RSO stanol } \\
\text { ester }(34 \mathrm{~g} / \mathrm{kg})\end{array}$} & \multicolumn{2}{|c|}{$\begin{array}{c}\text { RSO sterol } \\
\text { ester (34 g/kg) }\end{array}$} \\
\hline & Mean & SD & Mean & SD & Mean & SD & Mean & SD \\
\hline Animals per group $(n)$ & \multicolumn{2}{|c|}{18} & \multicolumn{2}{|c|}{17} & \multicolumn{2}{|c|}{17} & \multicolumn{2}{|c|}{18} \\
\hline Animals with macroscopic lesions $(n)$ & \multirow{2}{*}{\multicolumn{2}{|c|}{13}} & \multicolumn{2}{|c|}{$3^{* *}$} & \multirow{2}{*}{\multicolumn{2}{|c|}{$3^{\star *}$}} & \multirow{2}{*}{\multicolumn{2}{|c|}{$1^{* * *}$}} \\
\hline \multicolumn{4}{|l|}{ Aorta covered by plaque (\%) } & & & & & \\
\hline Cranial aorta & 36 & 34 & $1^{\star \star *}$ & 3 & $0^{\star \star \star}$ & 1 & $1^{\star \star \star}$ & 3 \\
\hline Median & \multirow{2}{*}{\multicolumn{2}{|c|}{$\begin{array}{c}25 \\
0-84\end{array}$}} & \multirow{2}{*}{\multicolumn{2}{|c|}{$\begin{array}{c}0 \\
0-11\end{array}$}} & \multirow{2}{*}{\multicolumn{2}{|c|}{$\begin{array}{c}0 \\
0-2\end{array}$}} & \multirow{2}{*}{\multicolumn{2}{|c|}{$\begin{array}{c}0 \\
0-14\end{array}$}} \\
\hline Range & & & & & & & & \\
\hline Thoracic aorta & 26 & 34 & $0^{\star \star \star}$ & 1 & $0^{\star *}$ & 0 & $0^{\star \star}$ & 0 \\
\hline Median & \multicolumn{2}{|c|}{4} & \multicolumn{2}{|c|}{0} & \multicolumn{2}{|c|}{0} & \multicolumn{2}{|c|}{0} \\
\hline Range & \multicolumn{2}{|c|}{$0-97$} & \multicolumn{2}{|c|}{$0-5$} & \multicolumn{2}{|c|}{-} & \multicolumn{2}{|c|}{ - } \\
\hline Abdominal aorta & 15 & 19 & $0^{\star \star \star}$ & 1 & $0^{\star \star \star}$ & 0 & $0^{\star \star \star}$ & 1 \\
\hline Median & \multirow{2}{*}{\multicolumn{2}{|c|}{$\begin{array}{c}8 \\
0-60\end{array}$}} & & & & & & \\
\hline Range & & & & & & & & \\
\hline Total (\%) & 25 & 27 & $0.4^{\star \star \star}$ & 1 & $0^{\star \star \star}$ & & 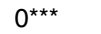 & \\
\hline Intima:media ratio & & & & & & & & \\
\hline Cranial aorta & 0.08 & 0.23 & $0.00^{\star \star \star}$ & 0.00 & $0.00^{\star \star \star}$ & 0.00 & $0.00^{\star \star \star}$ & 0.00 \\
\hline Median & & & & & & & & \\
\hline Range & 0.00 & & 0.00 & & 0.00 & & 0.00 & \\
\hline Thoracic aorta & $0 \cdot 15$ & 0.25 & $0.00^{\star \star *}$ & 0.01 & $0.00^{\star \star \star}$ & 0.00 & $0.00^{\star \star \star}$ & 0.00 \\
\hline Median & & & & & & & & \\
\hline Range & 0.00 & & 0.00 & & 0.00 & & 0.00 & \\
\hline Abdominal aorta & 0.21 & 0.36 & $0.01^{* *}$ & 0.02 & $0.00^{\star \star *}$ & 0.00 & $0.02^{\star *}$ & 0.00 \\
\hline Median & & & & & & & & \\
\hline Range & 0.00 & & 0.00 & & 0.00 & & 0.00 & \\
\hline Area of intima $\left(\mathrm{mm}^{2}\right)$ & & & & & & & & \\
\hline Cranial aorta & 0.25 & 0.63 & $0.00^{\star \star *}$ & 0.00 & $0.00^{\star \star *}$ & 0.00 & $0.00^{\star \star *}$ & 0.00 \\
\hline Median & & & & & & & & \\
\hline Range & 0.00 & & 0.00 & & 0.00 & & 0.00 & \\
\hline Thoracic aorta & 0.32 & 0.56 & $0.01^{\star *}$ & 0.02 & $0.00^{\star \star \star}$ & 0.00 & $0.00^{\star \star \star}$ & 0.00 \\
\hline Median & & & & & & & & \\
\hline Range & 0.00 & & 0.00 & & 0.00 & & 0.00 & \\
\hline Abdominal aorta & 0.31 & 0.47 & $0.01^{* *}$ & 0.04 & $0 \cdot 00^{\star \star *}$ & 0.00 & $0.02^{\star *}$ & 0.08 \\
\hline Median & & & & & & & & \\
\hline Range & 0.00 & & 0.00 & & 0.00 & & 0.00 & \\
\hline
\end{tabular}

Value was significantly different from that of the control group: ${ }^{\star \star} P<0.01,{ }^{\star \star \star} P<0.001$. 

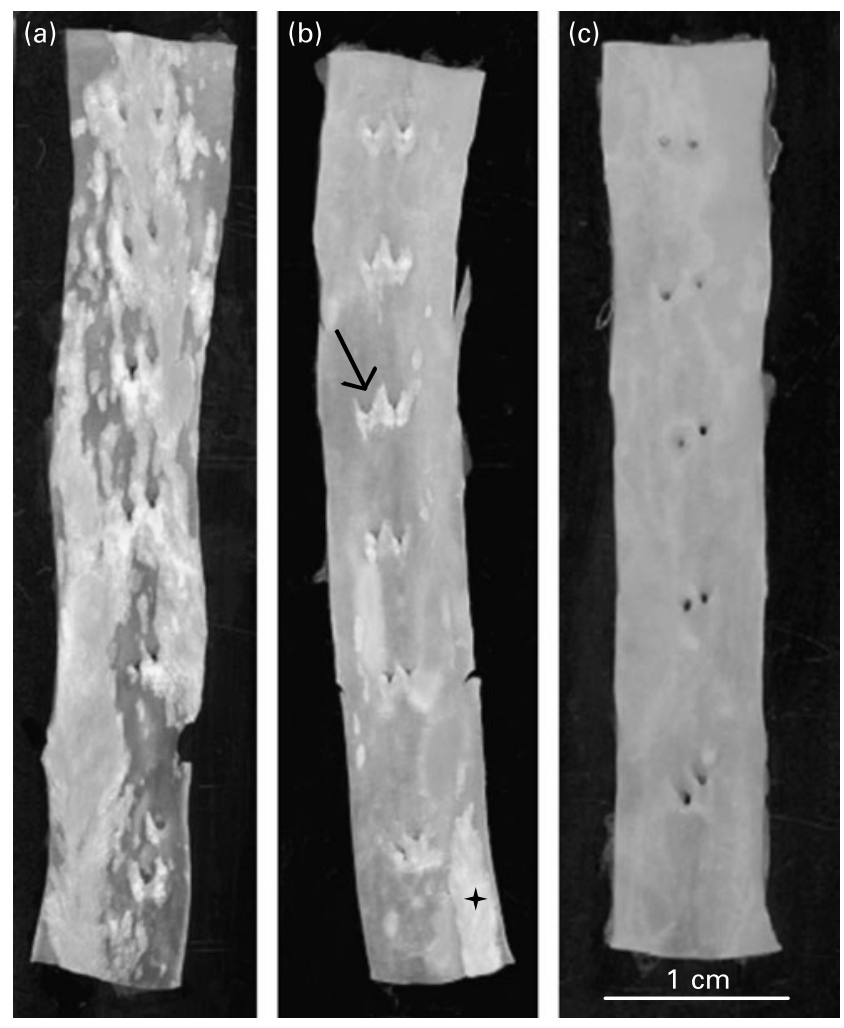

Fig. 6. Macroscopic photographs showing the endothelial surface of representative atherosclerotic lesions in the thoracic aorta. (a) A control animal with atherosclerotic plaques covering $68 \%$ of the thoracic aorta in big confluent areas and little spots. (b) An animal from the low-dose $(17 \mathrm{~g} / \mathrm{kg})$ rapeseed oil (RSO) stanol ester group with small atherosclerotic plaques covering a total of $4 \%$ of the surface in little spots mainly located around the intercostal arteries $(\downarrow)$ and one larger lesion at the bottom $(+)$. (c) A thoracic aorta without atherosclerotic changes representing any animal of the high-dose $(34 \mathrm{~g} / \mathrm{kg})$ RSO stanol or sterol ester groups.

\section{Discussion}

RSO plant sterol blends contain the unique brassicasterol in concentrations higher than what is allowed for plant sterol blends to be added to food products in the European Union $^{(23)}$. In the present study the effects of RSO plant sterol and stanol ester blends on blood lipids and experimental atherosclerosis were investigated in cholesterol-fed Hh-WHHL rabbits. In this model both RSO sterol and stanol esters had clear hypocholesterolaemic and anti-atherogenic effects.

Before and during the study the rabbits were fed a standard rabbit chow produced from natural plant components that may include rape. This explains the presence of plant sterols, including brassicasterol, in the feed and in plasma of all the rabbits before and after experimental feeding, and also in the control group as well as the RSO stanol ester groups. RSO sterol ester feeding markedly increased the plant sterol concentrations in the plasma overall, whereas RSO stanol ester feeding increased the plant stanol concentrations and lowered the plant sterol concentrations in the plasma compared with controls. The observed changes in the sterol and stanol concentrations in the plasma in response to treatment was in accordance with previous reports ${ }^{(14,15,34-36)}$. The mechanism by which stanol esters exert their plant sterol-lowering effect is not exactly known, but the observed effect has been described previously in a number of publications $^{(1,6,37,38)}$. A competitive incorporation based on total mass of plant stanols compared with plant sterols could be responsible for this effect. Another possibility which has been shown in human subjects ${ }^{(39)}$ is that a high intake of stanol esters leads to the esterification of cholesterol, plant sterols and re-esterification of free plant stanols in the gut.

In the present study the increase in plant stanols in plasma was comparable for the two dose levels of RSO stanol esters. This finding is in accordance with a previous study in Wistar rats, where increasing the dose of stanol esters from $17 \mathrm{~g} / \mathrm{kg}$ to $84 \mathrm{~g} / \mathrm{kg}$ did not cause significant changes in plasma plant stanol levels ${ }^{(40)}$. Thus, these observations indicate that the absorption of plant stanols is limited and dose independent, resulting in a saturation or threshold level in the blood. Campesterol was present in the highest concentrations of all plant sterols measured in the blood. This is in accordance with previous studies in rats and mice, showing that campesterol is the plant sterol taken up to the blood fastest and in highest concentrations due to its chemical composition ${ }^{(35,41,42)}$.

It is well known that plant sterols and stanols are not only taken up into the blood, but can also be found in different tissues following oral exposure. Plant sterols have been found in several tissues of mice ${ }^{(43)}$ and rats ${ }^{(42)}$, in brain tissue of Hh-WHHL rabbits ${ }^{(29)}$ and in aortic tissues of New Zealand White rabbits ${ }^{(34)}$. The present study is the first to report concentrations of plant sterols and stanols in intima of the cranial aorta. In the present study only campesterol in the RSO sterol ester group and campestanol in the RSO stanol ester groups were found in significantly increased concentrations in aortic tissue compared with the control group.

There was no significant difference in the amount of plant stanols incorporated into aortic tissue between the two RSO stanol ester groups. These findings suggest that a threshold level of plant stanols was obtained in aortic tissues in accordance with what was seen in plasma. Furthermore, the amounts of sitostanol and total plant stanols were not increased compared with the control group.

RSO plant stanol esters markedly reduced the total concentration of plant sterols both in plasma and in the cranial aorta, whereas RSO plant sterol esters caused significantly increased total concentrations of both plant sterols and plant stanols in plasma, but only plant sterols were increased in the cranial aorta. In the RSO sterol ester group the percentage of total plant sterols to cholesterol was comparable in plasma $(12 \%)$ and in the cranial aorta $(10 \%)$. The total concentration and percentage of plant sterols to cholesterol in plasma due to RSO sterol ester feeding was much higher than what has previously been reported in animal studies ${ }^{(14,43,44)}$. RSO sterol ester feeding led to a lowering of the sitosterol concentration in the cranial aorta. The preferential incorporation of campesterol over sitosterol seen in the present study is in accordance with results found in whole aortas from New Zealand White rabbits $^{(15)}$ and in different tissues of apoE*3-Leiden mice ${ }^{(43)}$ In the present study the percentages of phytosterols to cholesterol in plasma and intima of the cranial aorta were comparable within each group and positive correlations were observed for each group in percentages of phytosterols to cholesterol between plasma and intima. These results indicate that there was no preferential incorporation into aortic tissue of either plant stanols or plant sterols over cholesterol. 
Table 5. Microscopic qualitative evaluation of atherosclerotic lesions after rapeseed oil (RSO) stanol or sterol ester feeding for 18 weeks

\begin{tabular}{|c|c|c|c|c|}
\hline Group. . & Control & RSO stanol ester $(17 \mathrm{~g} / \mathrm{kg})$ & RSO stanol ester $(34 \mathrm{~g} / \mathrm{kg})$ & RSO sterol ester $(34 \mathrm{~g} / \mathrm{kg})$ \\
\hline Animals per group $(n)$ & 18 & 17 & 17 & 18 \\
\hline \multicolumn{5}{|l|}{ Cranial aortat } \\
\hline No lesions & 7 & 16 & 17 & 17 \\
\hline Lesions & 11 & $0^{\star \star \star}$ & $0^{\star \star \star}$ & $1^{\star \star \star}$ \\
\hline Fatty streak & 5 & 0 & 0 & 1 \\
\hline Fibrous plaque & 5 & 0 & 0 & 0 \\
\hline Advanced lesion & 1 & 0 & 0 & 0 \\
\hline \multicolumn{5}{|l|}{ Thoracic aorta } \\
\hline No lesions & 8 & 16 & 17 & 18 \\
\hline Lesions & 10 & $1^{*}$ & $0^{\star \star \star}$ & $0^{\star \star \star}$ \\
\hline Fatty streak & 0 & 0 & 0 & 0 \\
\hline Fibrous plaque & 7 & 2 & 0 & 0 \\
\hline Advanced lesion & 3 & 0 & 0 & 0 \\
\hline \multicolumn{5}{|l|}{ Abdominal aorta } \\
\hline No lesions & 8 & 15 & 17 & 17 \\
\hline Lesions & 10 & $2^{*}$ & $0^{\star \star \star}$ & $1^{\star \star \star}$ \\
\hline Fatty streak & 1 & 2 & 0 & 0 \\
\hline Fibrous plaque & 8 & 0 & 0 & 1 \\
\hline Advanced lesion & 1 & 0 & 0 & 0 \\
\hline
\end{tabular}

Number of lesions was significant different from that in the control group: ${ }^{*} P<0.05$, ${ }^{\star \star *} P<0.001$.

$\dagger$ For cranial aorta, data on one animal were missing in the $17 \mathrm{~g} / \mathrm{kg} \mathrm{RSO}$ stanol ester group.

Furthermore, the correlations are in agreement with other studies in human subjects and in experimental animals ${ }^{(10,45)}$.

Feeding RSO plant sterols with about $10 \%$ brassicasterol led to about a 5-fold increase in plasma concentrations of brassicasterol compared with control, but the absolute plasma concentration still remained at a low level compared with sitosterol and especially compared with campesterol. Furthermore, the concentration of the RSO-specific brassicasterol was not increased in the cranial aorta. A low plasma concentration and percentage of brassicasterol comparable with the control group indicate a low uptake of brassicasterol at least when fed as part of a plant sterol blend containing $90 \%$ other plant sterols. The low concentration of brassicasterol in aortic tissue further indicates that clearance from the blood is slower than of other plant sterols and that its incorporation into body tissues is limited compared with campesterol.

The long-term biological significance of plant sterols being present in the aortic wall following oral exposure has not been discussed in the scientific literature. However, evidence of profoundly disrupted cholesterol homeostasis in adrenal tissues with interferences of cholesterol regulation when plant sterols were present in this tissue has been reported ${ }^{(46)}$ while another study reports that cholesterol synthesis in brain tissue does not seem to be affected by the presence of RSO sterols or stanols ${ }^{(29)}$.

The dosage of RSO plant sterols and stanols was very high in the present study $(0.1 \mathrm{~g} / \mathrm{kg} \mathrm{BW}$ per $\mathrm{d})$ when compared with the daily intake considered optimal for cholesterol-lowering purposes in humans $(3 \mathrm{~g} / \mathrm{d}$ or $0.04 \mathrm{~g} / \mathrm{kg} \mathrm{BW})$. The high doses were chosen because rabbits have a metabolic rate approximately 2.5 times higher than humans ${ }^{(47)}$. Furthermore, these doses permitted the investigation of possible side effects of high exposure to brassicasterol through an RSO plant sterolcontaining diet. Clinical appearance, body weight, weight gain and feed intake were not affected, indicating that the dietary exposure to an RSO plant sterol blend with a high concentration of brassicasterol was well tolerated. The concentrations of plant sterols and stanols in plasma were much higher in the Hh-WHHL rabbits in the present study than those reported in human subjects eating food products with plant sterols or stanols $^{(36)}$. This is obviously partly due to the high dietary exposure to RSO sterol and stanol esters in the present study, but it is also explained by the higher plasma concentrations of plant sterols and stanols generally observed in studies with experimental animals compared with plasma concentrations obtained in human subjects consuming plant sterols.

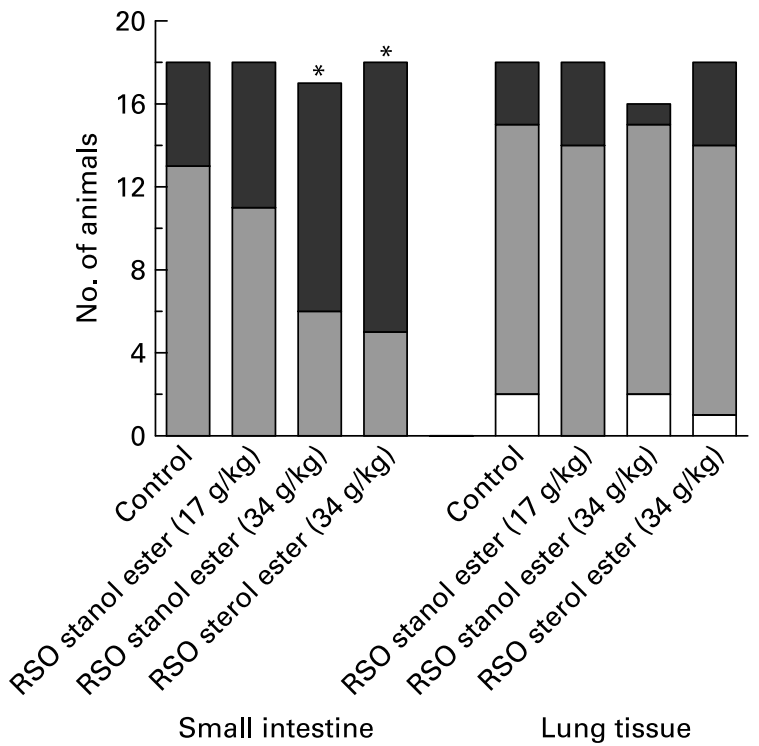

Fig. 7. Infiltration with macrophages in the small intestine and in lung tissue after rapeseed oil (RSO) stanol or sterol ester feeding for 18 weeks. ( $\square$ ), Pronounced infiltration; $(\square)$, slight infiltration; $(\square)$, no infiltration. * Pronounced infiltration was significantly increased in the small intestine of the high-dose $(34 \mathrm{~g} / \mathrm{kg}) \mathrm{RSO}$ stanol and sterol ester groups when compared with the control group $(P<0.05)$. 
In the present study dietary treatment with RSO plant sterols in high and stanols in low and high doses significantly reduced blood concentrations of total and LDL-cholesterol and inhibited the development of experimental atherosclerosis in Hh-WHHL rabbits. Thus, RSO plant sterol and stanol esters exert similar effects on experimental hypercholesterolaemia and atherosclerosis to plant sterols and stanols from other sources tested in other animal models ${ }^{(12,14-18)}$. It should be noted that the difference in total cholesterol levels reported in Fig. 2 and Table 3 was due only to different analytical methods. The enzymic method measures all sterols in plasma, whereas the GC-flame ionisation detection method enables a separation of the different sterols in the plasma. This explains why the total cholesterol concentration was higher when measured enzymically. The dissimilar results obtained by the two methods did not influence the conclusions of the study, as cholesterol levels were only used to perform intra-method comparisons.

In the present study all atherosclerosis parameters were significantly lower in the RSO stanol and sterol ester groups compared with the control group. The incidence, extent and severity of aortic atherosclerosis in the RSO plant sterol ester and stanol ester groups was very low compared with similar studies ${ }^{(10,14)}$. One possible reason for this could be that the mean plasma cholesterol levels remained at rather low levels throughout the study in response to the RSO sterol and stanol ester treatment.

In the present study the concentration of lathosterol, a precursor to cholesterol, was significantly lower both in plasma and in intima of the cranial aorta in all RSO stanol and sterol ester-treated groups compared with the control group. However, the lathosterol:cholesterol ratio, the indicator for cholesterol synthesis, was comparable for all groups only in plasma whereas it was significantly increased in the intima of the three treated groups compared with the control group. The findings in plasma are in contrast to the effects reported for human subjects and in other animal studies. In human subjects, both the concentration of lathosterol and the lathosterol: cholesterol ratio increased in plasma in response to exposure to plant sterols or stanols ${ }^{(36,48-50)}$. In apoE*3-Leiden transgenic mice fed a Western-type diet with plant stanol esters added, the lathosterol:cholesterol ratio was increased in plasma $^{(51)}$. Furthermore, increased total lathosterol has been reported in plasma of female Wistar rats exposed to dietary doses of plant stanol esters ${ }^{(40)}$. The present study is the first to report effects of plant sterols and stanols on the lathosterol: cholesterol ratio in aortic intima from cholesterol-fed animals. The observed increase in the lathosterol:cholesterol ratio in the cranial aorta in all of the treated groups compared with the control group may not be a sign of increased cholesterol synthesis in the intima related to treatment. More probably the increased ratio was caused by a larger decrease in the cholesterol content than in the lathosterol content in the intima.

The significant effect of RSO sterol ester feeding on TAG levels in plasma has not been reported in other experimental animal models, whereas the observed decrease in the control and RSO stanol ester groups through the first 6 weeks of the study was a response to changed dietary intake of fat which has been described previously ${ }^{(52)}$. It should be noted that the rabbits were weaned the day before initiation of the study and received during the suckling period their mothers' milk with a fat content of approximately $13 \%$ fat $^{(53)}$.

Infiltrations with macrophages in the small intestines could be a local adaptive response to the presence of high concentrations of sterol and stanol esters in the gut. These findings have not been reported in other animal models in relation to plant sterol or stanol ester feeding.

In conclusion, the present study demonstrated that RSO plant stanols and RSO sterols with a naturally high concentration of brassicasterol are well tolerated, have hypocholesterolaemic effects and inhibit experimental atherosclerosis in cholesterol-fed Hh-WHHL rabbits. It is generally accepted by scientific experts that human consumers of plant sterolor stanol-enriched food products can reduce their risk of CVD by lowering cholesterol levels in the blood when eating these products. Nevertheless, intervention studies showing that plant sterols or stanols reduce the risk of CVD are unavailable ${ }^{(2)}$. Published animal studies show contradictory results on regression and retardation of atherosclerosis and further studies are needed to elucidate the effect of plant sterol and stanol ester feeding on animals with established atherosclerosis.

\section{Acknowledgements}

The study was funded solely by the European Union project 'NOFORISK: Quantitative risk assessment strategies for novel food' in the 6th Framework Programme (grant no. FP6-506387).

The authors wish to thank Merete Lykkegaard, Karen Roswall, Joan Frandsen, Silvia Friedrichs, Meryem Gültekin, Anne Ørngreen and animal technicians for technical assistance.

M. S. was a $\mathrm{PhD}$ student on the project and responsible for study design and execution, histology and evaluation of atherosclerosis endpoints, statistical analyses and writing of the manuscript. C. F. was responsible for acquisition of plant sterol and stanol data in plasma and tissues. K. P. and M. P. were involved in study design and manuscript preparation. I. W. was involved in study design and critical revising of the manuscript and provided the test material. D. L. was responsible for measurements of plant sterols and stanols in plasma and tissues and was involved in study design and critical revising of the manuscript. A. M. was responsible for conception and design, interpretation and writing and critical revising of the manuscript. All authors approved the final version of the manuscript.

The authors have no conflicts of interest to disclose.

\section{References}

1. Thompson GR \& Grundy SM (2005) History and development of plant sterol and stanol esters for cholesterol-lowering purposes. Am J Cardiol 96, 3D-9D.

2. European Food Safety Authority (2008) Scientific Opinion of the Panel on Dietetic Products, Nutrition and Allergies on a request related to the scientific substantiation of a health claim on plant stanol esters and lower/reduced blood cholesterol and reduced risk of (coronary) heart disease. EFSA $J$ 852, 1-13.

3. European Food Safety Authority (2008) Scientific Opinion of the Panel on Dietetic Products, Nutrition and Allergies on a scientific substantiation of a health claim on plant sterols 
and lower/reduced blood cholesterol and reduced risk of (coronary) heart disease. EFSA $J$ 781, 1-12.

4. Vanstone CA, Raeini-Sarjaz M, Parsons WE, et al. (2002) Unesterified plant sterols and stanols lower LDL-cholesterol concentrations equivalently in hypercholesterolemic persons. Am J Clin Nutr 76, 1272-1278.

5. Pollak OJ (1953) Reduction of blood cholesterol in man. Circulation 7, 702-706.

6. O'Neill FH, Sanders TA \& Thompson GR (2005) Comparison of efficacy of plant stanol ester and sterol ester: short-term and longer-term studies. Am J Cardiol 96, 29D-36D.

7. Jones PJ, Ntanios FY, Raeini-Sarjaz M, et al. (1999) Cholesterol-lowering efficacy of a sitostanol-containing phytosterol mixture with a prudent diet in hyperlipidemic men. Am J Clin Nutr 69, 1144-1150.

8. Weststrate JA \& Meijer GW (1998) Plant sterol-enriched margarines and reduction of plasma total- and LDL-cholesterol concentrations in normocholesterolaemic and mildly hypercholesterolaemic subjects. Eur J Clin Nutr 52, 334-343.

9. Silbernagel G, Fauler G, Renner W, et al. (2009) The relationships of cholesterol metabolism and plasma plant sterols with the severity of coronary artery disease. J Lipid Res 50, 334-341.

10. Weingartner O, Lutjohann D, Ji S, et al. (2008) Vascular effects of diet supplementation with plant sterols. $\mathrm{J} \mathrm{Am} \mathrm{Coll} \mathrm{Cardiol}$ 51, 1553-1561.

11. John S, Sorokin AV \& Thompson PD (2007) Phytosterols and vascular disease. Curr Opin Lipidol 18, 35-40.

12. Patel MD \& Thompson PD (2006) Phytosterols and vascular disease. Atherosclerosis 186, 12-19.

13. Wilund KR, Yu L, Xu F, et al. (2004) No association between plasma levels of plant sterols and atherosclerosis in mice and men. Arterioscler Thromb Vasc Biol 24, 2326-2332.

14. Plat J, Beugels I, Gijbels MJ, et al. (2006) Plant sterol or stanol esters retard lesion formation in LDL receptor-deficient mice independent of changes in serum plant sterols. J Lipid Res 47, 2762-2771.

15. Kritchevsky D, Tepper SA, Czarnecki SK, et al. (2003) Serum and aortic levels of phytosterols in rabbits fed sitosterol or sitostanol ester preparations. Lipids 38, 1115-1118.

16. Moghadasian MH, McManus BM, Pritchard PH, et al. (1997) 'Tall oil'-derived phytosterols reduce atherosclerosis in apoEdeficient mice. Arterioscler Thromb Vasc Biol 17, 119-126.

17. Ntanios FY, Jones PJ \& Frohlich JJ (1998) Dietary sitostanol reduces plaque formation but not lecithin cholesterol acyl transferase activity in rabbits. Atherosclerosis 138, 101-110.

18. Volger OL, Mensink RP, Plat J, et al. (2001) Dietary vegetable oil and wood derived plant stanol esters reduce atherosclerotic lesion size and severity in apoE*3-Leiden transgenic mice. Atherosclerosis 157, 375-381.

19. Moghadasian MH, Godin DV, McManus BM, et al. (1999) Lack of regression of atherosclerotic lesions in phytosterol-treated apo E-deficient mice. Life Sci 64, 1029-1036.

20. Vlahakis C \& Hazebroek J (2000) Phytosterol accumulation in canola, sunflower, and soy bean oils: effect of genetics, planting location, and temperature. J Am Oil Chem Soc 77, $49-53$.

21. Phillips KM, Ruggio DM, Toivo JI, et al. (2008) Free and esterified sterol composition of edible oils and fats. J Food Compost Anal 15, 123-142.

22. Amar S, Becker HC \& Möllers C (2008) Genetic variation and genotype $\mathrm{x}$ environment interactions of phytosterol content in three doubled haploid populations of winter rapeseed. Crop Sci 48, 1000-1007.

23. European Union Commission (2000) Commission decision of 24 July 2000 on authorising the placing on the market of 'yellow fat spreads with added phytosterol esters' as a novel food or novel food ingredient under Regulation (EC) No 258/ 97 of the European Parliament and of the Council. OJEC L200 43, 59-60.

24. Atkinson JB, Hoover RL, Berry KK, et al. (1989) Cholesterolfed heterozygous Watanabe heritable hyperlipidemic rabbits: a new model for atherosclerosis. Atherosclerosis 78, 123-136.

25. Esper E, Runge WJ, Gunther R, et al. (1993) Natural history of atherosclerosis and hyperlipidemia in heterozygous WHHL (WHHL-Hh) rabbits. II. Morphologic evaluation of spontaneously occurring aortic and coronary lesions. J Lab Clin Med 121, 103-110.

26. Dowell FJ, Hamilton CA, Lindop GB, et al. (1995) Development and progression of atherosclerosis in aorta from heterozygous and homozygous WHHL rabbits: effects of simvastatin treatment. Arterioscler Thromb Vasc Biol 15, 1152-1160.

27. Kinscherf R, Kamencic H, Deigner HP, et al. (2003) Hypercholesterolemia-induced long-term increase of macrophages in the myocardium of New Zealand White rabbits. Cells Tissues Organs 174, 184-193.

28. Mortensen A, Hansen BF, Frandsen H, et al. (1995) Extravascular lipid deposition and morphology of atherosclerosis in heterozygous WHHL rabbits fed vegetable $(n-6)$ and marine (n-3) oils. Scand J Lab Anim Sci 22, 213-225.

29. Fricke CB, Schroder M, Poulsen M, et al. (2007) Increased plant sterol and stanol levels in brain of Watanabe rabbits fed rapeseed oil derived plant sterol or stanol esters. Br J Nutr 98, 890-899.

30. Terpstra AH, Woodward CJ \& Sanchez-Muniz FJ (1981) Improved techniques for the separation of serum lipoproteins by density gradient ultracentrifugation: visualization by prestaining and rapid separation of serum lipoproteins from small volumes of serum. Anal Biochem 111, 149-157.

31. Hansen BF, Mortensen A, Hansen JF, et al. (1994) Atherosclerosis in Watanabe heritable hyperlipidaemic rabbits. Evaluation by macroscopic, microscopic and biochemical methods and comparison of atherosclerosis variables. APMIS 102, 177-190.

32. Gundersen HJ, Bendtsen TF, Korbo L, et al. (1988) Some new, simple and efficient stereological methods and their use in pathological research and diagnosis. APMIS 96, 379-394.

33. Lütjohann D, Brzezinka A, Barth E, et al. (2002) Profile of cholesterol-related sterols in aged amyloid precursor protein transgenic mouse brain. J Lipid Res 43, 1078-1085.

34. Bhattacharyya AK \& Lopez LA (1979) Absorbability of plant sterols and their distribution in rabbit tissues. Biochim Biophys Acta 574, 146-153.

35. Ostlund RE Jr (2002) Phytosterols in human nutrition. Annu Rev Nutr 22, 533-549.

36. Hallikainen MA, Sarkkinen ES, Gylling H, et al. (2000) Comparison of the effects of plant sterol ester and plant stanol ester-enriched margarines in lowering serum cholesterol concentrations in hypercholesterolaemic subjects on a low-fat diet. Eur J Clin Nutr 54, 715-725.

37. Lutjohann D, Bjorkhem I, Beil UF, et al. (1995) Sterol absorption and sterol balance in phytosterolemia evaluated by deuterium-labeled sterols: effect of sitostanol treatment. J Lipid Res 36, $1763-1773$.

38. Plat J \& Mensink RP (2005) Plant stanol and sterol esters in the control of blood cholesterol levels: mechanism and safety aspects. Am J Cardiol 96, 15D-22D.

39. Nissinen MJ, Gylling H \& Miettinen TA (2008) Effects of dietary cholesterol and fat on serum non-cholesterol sterols according to different apolipoprotein E subgroups among healthy men. Br J Nutr 100, 373-379.

40. Turnbull D, Whittaker MH, Frankos VH, et al. (1999) 13-Week oral toxicity study with stanol esters in rats. Regul Toxicol Pharmacol 29, 216-226. 
41. Igel M, Giesa U, Lutjohann D, et al. (2003) Comparison of the intestinal uptake of cholesterol, plant sterols, and stanols in mice. J Lipid Res 44, 533-538.

42. Sanders DJ, Minter HJ, Howes D, et al. (2000) The safety evaluation of phytosterol esters. Part 6 . The comparative absorption and tissue distribution of phytosterols in the rat. Food Chem Toxicol 38, 485-491.

43. Plat J, de Jong A, Volger OL, et al. (2008) Preferential campesterol incorporation into various tissues in apolipoprotein $\mathrm{E}^{*} 3$ Leiden mice consuming plant sterols or stanols. Metabolism 57, $1241-1247$.

44. Ntanios FY, van de Kooij AJ, de Deckere EA, et al. (2003) Effects of various amounts of dietary plant sterol esters on plasma and hepatic sterol concentration and aortic foam cell formation of cholesterol-fed hamsters. Atherosclerosis 169, 41-50.

45. Helske S, Miettinen T, Gylling H, et al. (2008) Accumulation of cholesterol precursors and plant sterols in human stenotic aortic valves. J Lipid Res 49, 1511-1518.

46. Yang C, Yu L, Li W, et al. (2004) Disruption of cholesterol homeostasis by plant sterols. J Clin Invest 114, 813-822.

47. Hau J \& Poulsen OM (1988) Doses for laboratory animals based on metabolic rate. Scand J Lab Anim Sci 15, 81-83.
48. Mensink RP, Ebbing S, Lindhout M, et al. (2002) Effects of plant stanol esters supplied in low-fat yoghurt on serum lipids and lipoproteins, non-cholesterol sterols and fat soluble antioxidant concentrations. Atherosclerosis 160, 205-213.

49. Plat J \& Mensink RP (2002) Effects of plant stanol esters on LDL receptor protein expression and on LDL receptor and HMG-CoA reductase mRNA expression in mononuclear blood cells of healthy men and women. FASEB $J$ 16, 258-260.

50. Vanhanen HT, Blomqvist S, Ehnholm C, et al. (1993) Serum cholesterol, cholesterol precursors, and plant sterols in hypercholesterolemic subjects with different apoE phenotypes during dietary sitostanol ester treatment. J Lipid Res 34, 1535-1544.

51. Volger OL, van der Boom H, de Wit EC, et al. (2001) Dietary plant stanol esters reduce VLDL cholesterol secretion and bile saturation in apolipoprotein $\mathrm{E}^{*} 3$-Leiden transgenic mice. Arterioscler Thromb Vasc Biol 21, 1046-1052.

52. Mortensen A \& Frandsen H (1996) Reproductive performance and changes in blood lipids in breeding females and in growing Watanabe heritable hyperlipidaemic and New Zealand White rabbits. Lab Anim 30, 252-259.

53. Hagen KW (1974) Colony husbandry. In Biology of the Laboratory Rabbit, 2nd ed., pp. 23-47 [SH Weisbroth, RE Flatt and AL Kraus, editors]. New York: Academic Press. 